\title{
The Role of Animal Source Foods in Improving Nutritional Health in Urban Informal Settlements: Identification of Knowledge Gaps and Implementation Barriers
}

\author{
Allison E. James* and Guy H. Palmer \\ Paul G. Allen School for Global Animal Health, Washington State University, PO Box 647040, Pullman, WA \\ 99164-7040, USA
}

\begin{abstract}
Childhood undernutrition is a health crisis in the rapidly expanding informal settlements of low-income countries worldwide. Nearly half of Kenyan children in the Kibera settlement, in Nairobi, were reported to be stunted, indicating low height-for-age. Stunted children are at greater risk for poor cognitive and physical health outcomes in the long-term, problems that tend to be perpetuated in subsequent generations. Animal-source foods (ASF) supply a calorically dense source of micro- and macronutrients, and supplementation with ASF has been shown to improve linear growth and cognition. Correspondingly, increasing consumption of ASF by pregnant women and children has been proposed as a means to disrupt the intergenerational cycle of undernutrition caused by food insecurity. Household surveys indicate that consumption of ASF is low in urban slums, despite the availability of these foods in local markets. Here we review the studies addressing the role of ASF in the diets of the urban poor and identify knowledge gaps relevant to improving nutrition by increasing consumption of ASF. Based predominantly on studies in Kibera and greater Nairobi, these gaps include determining the minimal amount and frequency of dietary ASF to prevent stunting, defining how consumer preferences, markets, and income interact to impede or promote ASF consumption, and understanding the interaction between diet and both clinical and sub-clinical enteric disease on growth outcomes.
\end{abstract}

Keywords: Maternal health, Child malnutrition, Undernutrition, Food security, Informal urban settlements.

\section{INTRODUCTION}

By 2050 it is projected that the human population will reach 9.3 billion, and that nearly $70 \%$ of people will live in cities. Developing countries will account for greater than $90 \%$ of both the population and urbanization rates. The trend toward urbanization in developing countries has been, and will continue to be swift: in 1970, $25 \%$ of the developing world lived in cities, in 2010 this number nearly doubled, and by 2050, a projected $64 \%$ will be urbanites [1]. Many cities, particularly those in low-income countries, have not kept pace with this rapid transition, resulting in expansion of informal settlements (slums). By 2001, slums were home to $43 \%$ of the developing world's urban population, with that number reaching $70 \%$ in sub-Saharan Africa [2]. Characteristics of slums include inadequate access to safe water, poor sanitation, overcrowding, and low-quality housing. Health outcomes are poor as a result of these unhealthy living conditions, in addition to the lack of health services and nutritional deficiencies [2, 3]. While infrastructure upgrading within the informal settlements will be necessary to match the living conditions of other urban residents, there is an immediate need and opportunity to improve nutrition. Near-term solutions are possible

*Address correspondence to this author at the Paul G. Allen School for Global Animal Health, Washington State University, PO Box 647040, Pullman, WA 99164-7040, USA; Tel: (509)-335-6343; Fax: (509) 335-6328;

E-mail: eavey@vetmed.wsu.edu because food insecurity in the settlements, in both quality and quantity, is often a result of inaccessibility, rather than unavailability [3]. The informal settlements of Nairobi illustrate a situation where poor nutritional health outcomes result from food inaccessibility. While this article focuses on Nairobi, many of the identified barriers and knowledge gaps are common to other cities experiencing rapid urban growth with expansion of informal settlements.

Of the 3.1 million Nairobi residents, approximately $60-70 \%$ live in informal settlements [4, 5].Population growth rates in Nairobi County are $4 \%$ annually, and an estimated $75 \%$ of the new growth will occur in the slums [5-7]. The population influx, in addition to poverty, substandard living conditions, and lack of social services, presents multiple challenges to meeting sustainable development goals $[2,8]$. A persistent and deepening problem is undernutrition; data from a 2008 study by Olack et al. in Kibera, Nairobi's largest informal settlement, revealed alarming rates of undernourishment. In that survey, $11.8 \%$ of children under five were found to be underweight (low weight-for-age and sex), 47\% were stunted (low heightfor-age), and $2.6 \%$ were wasted (low weight-for-height) [9]. The proportion of children stunted in this study far exceeded that reported in the 2008-09 Kenya Demographic and Health Survey, where stunting rates in the city of Nairobi were $28.5 \%$ and national rates were $35.3 \%$ [10]. The discordant results suggest a serious underestimation of the problem in the urban 
slums [9]. The indicator in itself implies a chronic food insecurity problem, whereby stunting is a result of "prolonged or recurrent episodes of inadequate nutrition" [11-13]. In contrast, wasting is an indicator of acute weight loss $[12,13]$.

The ramifications of childhood undernutrition are severe. Inadequate nutrition leads to a number of physical disabilities, impaired cognitive development, and an increased risk of morbidity due to infectious disease [12]. Moreover, WHO estimates that undernutrition underpins more than half of all child deaths worldwide [14]. The long-term consequences of childhood undernutrition extend beyond a shortened stature. Stunted children enter adulthood into a cycle where their babies are small for gestational age, have low birth weight, have poorer responses to vaccines, and are at greater risk for infant mortality- all factors that can perpetuate poor health and development in subsequent generations [15, 16]. Paradoxically, early childhood undernutrition also contributes to the burgeoning problem of overweight and chronic disease $[15,17]$. A Kenyan study found that childhood stunting and maternal overweight each increased the odds of overweight/obesity by approximately $70 \%$, revealing that these children do not easily escape the intergenerational cycle of poor health outcomes [18]. Many interrelated factors are associated with child malnutrition, including suboptimal breastfeeding, infectious disease, and inadequate maternal and child intake of total energy, micronutrients, and protein [12, 19-21]. Childhood undernutrition is also negatively associated with individual and societal economic outcomes. Stunted children enroll in school at a later age, if at all, and receive fewer years of formal education [22, 23]. Based on the estimate that each year of schooling increases adult income by $9.7 \%$, the economic consequences for the stunted individual are dire with many remaining in poverty [22]. Conversely, a significant inverse association exists between declining stunting incidence and national economic growth rates $[24,25]$; economic growth has been shown to parallel improvements in nutritional health, alongside an increased participation in the labor force by healthier adults [26]. Consequently, it has been proposed that policies and practices that promote childhood nutritional health are integral to long-term economic development.

Food security is "when all people at all times have access to sufficient, safe, and nutritious food to maintain a healthy and active life" [27]. For residents of slums, food security is the exception rather than the rule. A recent paper by Kamau et al. analyzed survey data from Nairobi households for food consumption and expenditure. The results revealed that $44 \%$ of households sampled in all of Nairobi were food insecure; when disaggregated by income, $80 \%$ of the lowest income quintile were food insecure [28]. As expected, the greatest share of household expenditures for this quintile was for food (49\%). A comparison of the findings from 2003 to 2009 indicated that while the average total household expenditure in the lowest quintile increased by $9 \%(12,841$ to 13,979 $\mathrm{KSh}$ ), the average food expenditure more than doubled (114\%; 3,208 KSh to 6,876) [29]. This supports that the modest increase in total household spending, an indicator of income, was insufficient for keeping up with rising food prices during this period.

Would increased consumption of net calories in the form of staple foods (maize, bananas, potatoes, wheat and rice) reduce the rate of child stunting in the urban informal settlements [29]? For nutrition, it is difficult to ascertain the impact of supplementation with energy, protein, or micronutrients alone because increased consumption of protein, for example, is usually accompanied by an increase in energy and micronutrient consumption [20, 30]. Nonetheless, animal-source foods (ASF) have been shown to have a positive impact on physical growth and cognition in otherwise vulnerable Kenyan children [31-35]. A number of observational studies positively associate the consumption of ASF to increased weight gain in pregnancy, increased birth weight and length, postnatal infant growth, linear growth in toddlers, better cognitive outcomes, and improved physical activity levels [20]. ASF constitute a dense, high quality source of protein and energy that readily supplies essential amino acids. Furthermore, meat and milk contain iron, zinc, vitamin $A$, vitamin $B_{12}$, and calcium- micronutrients that are crucial for proper physical and cognitive development, as well as for maternal health during pregnancy and lactation $[15,20]$. The nutrients supplied by ASF are also readily digested and absorbed, as opposed to certain plant-based foods that contain compounds (phytates, oxalates, and tannins) that lower the bioavailability of some micronutrients such as iron and zinc. Conversely, the presence of heme protein in meat improves the absorption of iron and zinc from both ASF and plant foods $[19,20,36-38]$. In high-income countries, the consumption of ASF has been associated with chronic diseases such as cancer, diabetes, and cardiovascular disease. Indeed, ASF are energy dense, and over-consumption of ASF is a 
contributing factor related to obesity. In developing countries, the dual problems of undernourishment and obesity increasingly coexist. In the urban slums of Kenya, where stunting is prevalent, $43 \%$ of adult females and $17 \%$ of males were found to be overweight or obese [39]. As we discuss next, however, the urban poor infrequently consume ASF due to its relatively high cost. While increasing rates of obesity in slums is alarming, this more likely reflects lifestyle changes that result from urban life. These changes include less physical activity, availability of inexpensive ready-to-eat foods, and the substitution of calorically dense foods in place of healthier foods [18, 40-43].

\section{CONSUMPTION OF ASF IN NAIROBI'S SLUMS}

Despite the nutritional benefits of ASF, little is consumed by the urban poor. In 2009, Nairobi households whose income fell in the lowest quintile had an average monthly food budget of $1,362 \mathrm{KSh}$ per adult equivalent and allocated $13 \%$ of this to dairy products, and another $15 \%$ to meat and eggs (Table 1). Comparatively, the highest income quintile spent 5,014 KSh per adult equivalent per month on food, $17 \%$ of this was used to purchase dairy products, and $23 \%$ was spent on meat and eggs [29]. A similar 2003 household survey looked more closely at ASF. This report found that all income levels spent the most on beef, followed by chicken, then eggs. However, as expected, great disparities existed between the urban poor and the wealthy in annual consumption of meat. For beef and chicken, consumption for the wealthiest income quintile was 2.5 higher than the poorest quintile
[44]. Consumption of eggs and milk followed a similar trend. Liquid milk was, by far, the most commonly consumed dairy product across all incomes in Nairobi, but proportionally more pasteurized milk and yogurt were consumed as incomes increased [45]. The FAO recommends a minimum of approximately $20 \mathrm{~g}$ of animal protein per person per day [46]. Assuming equal access throughout the year, the urban poor consume only $75 \%$ of the yearly ASF recommendation, while the wealthy consume $190 \%$.

\section{BARRIERS TO INCREASING CONSUMPTION OF ANIMAL SOURCE FOODS}

In Kenya's urban areas, food is available in both formal and informal marketing sectors, and acquired through cash transactions [29, 44, 45]. Because the market supplies $90 \%$ of food to Nairobi's slum population, low purchasing power is the major impediment to procuring ASF $[47,48]$. Would policies that effectively reduce the cost of ASF to the urban poor increase consumption and, if so, what level of price reduction would be targeted to promote a desired level of consumption? The price elasticity of demand for a commodity measures how much more of that item will be purchased, and therefore consumed, given a percentage change in the price. Animal-source foods are generally shown to have high, but variable, price elasticities in low-income populations: small decreases in the price of meat and milk result in proportionately larger increases in their purchase. Price elasticities are determined by many factors, including household income, consumer preferences, and the availability and cost of substitutes [49]. The multifactorial price

Table 1: ASF Expenditure and Consumption in Nairobi ${ }^{\mathrm{a}}$

\begin{tabular}{|c|c|c|}
\hline & Lowest Income Quintile & Highest Income Quintile \\
\hline \multicolumn{3}{|l|}{ Food Budget $^{b}$} \\
\hline Total Monthly Food Budget (Ksh) ${ }^{c}$ & 1,362 & 5,014 \\
\hline$\%$ Meat and Eggs (Ksh) & $15 \%(203)$ & $23 \%(1,170)$ \\
\hline \% Dairy (Ksh) & $13 \%(176)$ & $17 \%(856)$ \\
\hline \multicolumn{3}{|l|}{ ASF Consumption ${ }^{b}$} \\
\hline Beef and Chicken (kg) & 15.3 & 41.7 \\
\hline Eggs (kg) & 4.3 & 10.7 \\
\hline Dairy (kg) & 4.3 & 9 \\
\hline \% Dairy as Pasteurized Milk (kg) & $51 \%(2.2)$ & $70 \%(6.3)$ \\
\hline \% Dairy as Yogurt (kg) & $0.5 \%(0.2)$ & $12 \%(1.1)$ \\
\hline
\end{tabular}

${ }^{a}$ Data derived from references [29], [45, 46].

${ }^{\mathrm{b}} \mathrm{Food}$ budget and consumption values are per adult equivalent.

${ }^{\mathrm{C}} \mathrm{Ksh}=$ Kenyan shilling. 
elasticity, then, varies substantially between and within populations. Using Nairobi household survey data, the demand for dairy and dairy products for the poor was shown to increase by $14.9 \%$ for every $10 \%$ decrease in price. For beef/beef products and poultry, the same decrease in price results in a $17.7 \%$ and $21.2 \%$ increase in demand, respectively [50]. Price elasticities often increase as incomes decrease, suggesting that price shocks impact consumption of all foods more for the poor [51]. The 2008 food price crisis, when the national food price index rose rapidly by $70 \%$, was detrimental to the already tenuous food accessibility situation of the urban slums [50]. During the crisis, a $56 \%$ increase in the price of milk, for example, resulted in a $33 \%$ decrease in the purchase of milk in all of Nairobi [48]. High prices force many into hunger and induce coping strategies that exacerbate poor nutritional health outcomes- decreasing portion sizes, consumption of fewer meals, reduction of food diversity, and the purchase of cheaper foods that are often lower in nutritional value [52]. Given price elasticities, policies that protect the lowest income consumers from rapid food price increases and household economic shocks are likely to have disproportionately beneficial effects on ASF consumption and overall nutrition.

Likewise, if incomes were increased, would Nairobi's urban poor consume more ASF? Indeed, trends in household surveys indicate that consumption of ASF increases with greater income. Income elasticities calculate the impact of different levels of income on the demand of a commodity. Many ASF are broadly characterized as income elastic, but like price elasticities, are multifactorial and highly variable. Expenditure elasticities can be used as a proxy for income elasticities when income data are not available. Musyoka et al. (2010) found that in Nairobi, a 10\% increase in total food expenditures was shown to result in $14.2 \%$ and $11 \%$ greater demand for poultry and beef, respectively, for the urban poor. To illustrate the impact of income, the same increase in income for wealthier Nairobi residents results in minimal changes in demand for poultry and beef [50]. These results support the notion that meat is a luxury good and considered inaccessible to those in extreme poverty. Importantly, similar studies in other areas of Kenya reveal different results in income elasticities for meat, as well as preference for different kinds of meat, reflecting the caution that must be applied when extrapolating elasticity results outside of the study population [53, 54]. Nonetheless, the data suggests that consumption of ASF would increase with increased income. However, with roughly half of slum dwellers having unstable employment, and another quarter economically inactive, passive reliance on increasing incomes alone is unlikely to improve nutritional outcomes in the near-term [55].

Price and income elasticity studies can inform policy-making decisions that would increase consumption of ASF for the urban poor. More comprehensive and current studies are needed to understand how specific policies impact ASF consumption and the overall nutrition of the urban poor. In lieu of policy changes, a number of aid programs are essentially increasing demand of ASF by the urban poor through cash transfer and voucher programs. Cash transfers increase income to food insecure households while vouchers are spent like cash in markets where they are redeemed for food items. The application and outcomes of conditional cash transfers, those when cash transfer is contingent upon actions of the family to meet certain health or education requirements, are promising. These programs are showing increased school enrollment, more use of preventive health systems, and improvement of child health and nutrition [56]. In addition, conditional cash transfer programs in several countries were shown to improve caloric quality through dietary diversity and increased consumption of ASF. Outcomes on indicators of child nutrition have been less consistent, with some programs showing no difference in heightfor-age, and others showing a significant difference [56]. A recent analysis of aid programs (non-conditional and voucher programs) in Nairobi's Mathare settlement found that maize, maize meal, and pulses were the most likely foods purchased with transferred cash or vouchers. Because the mean marginal propensity to consume a monthly 1,000 KSh per household cash transfer as food was only 0.32 , the authors concluded that consumption needs for slum dwellers extends beyond food [47]. Thus, the urban poor enrolled in this program continue to purchase only basic, low-quality foods. Given the level of poverty and modest cash transfer, this result is unsurprising and underscores the need for 'generous' and 'well-structured' aid programs [56]. In addition, aid programs must be outcome driven so that objective impacts on child malnutrition, such as changes in stunting rates, can be adequately assessed.

Lastly, point-of-sale practices may exclude the urban poor from ASF. Markets where urban consumers purchase foods differ by socioeconomic status. The 
poorest consumers rarely shop at large supermarkets for any of their ASF. This channel is frequented more as income increases, particularly for the purchase of eggs and chicken. These patterns pose an interesting cost dynamic, whereby the urban poor spend more per $\mathrm{kg}$ on eggs than the wealthy. This discrepancy is likely due to the discount afforded to wealthier consumers by supermarket chains for buying in bulk. Conversely, while the cost of chicken per $\mathrm{kg}$ among the income quintiles is fairly similar, the chicken purchased by the poor often comes from smaller retail outlets, where it is sold whole [44]. Because of the greater total cost of buying a whole chicken rather than smaller portions, the urban poor may be unable to regularly purchase this meat. For increasing consumption of ASF in the slums, the channels for obtaining food present a double-edged sword: undivided, or bulk foods, should encourage consumption by virtue of being less expensive per unit, but they also exclude those with limited purchasing power at any given time from routine consumption. Interestingly, consumers in all income quintiles purchase most raw and pasteurized milk from hawkers and dukas (small retail stores), respectively, where prices remain the same irrespective of socioeconomic status. Moreover, hawkers often provide door-to-door services with low prices, making it a convenient avenue across all incomes for the purchase of raw milk [45]. This indicates the potential for marketing and packaging solutions to promote improved access to ASF by the urban poor.

\section{ADDRESSING KNOWLEDGE GAPS}

While there is strong evidence for the role of increased consumption of ASF in promoting maternal and child health, there are multiple gaps in our knowledge regarding the minimal levels of specific ASF required for healthy development in the nutritional and environmental context of crowded urban settlements. In addition, understanding which public policies and private market actions improve or jeopardize food security provide opportunities to implement change. While our discussion focuses on food insecurity in the urban settlements in Nairobi, these questions broadly apply to informal settlements facing poor nutritional health outcomes worldwide.

\section{What are the minimum amounts of ASF that suffice to prevent stunting, and what frequency should they be consumed?}

Few longitudinal studies have been done to answer this question. The Nutrition Collaborative Research
Support Program was an observational study in the 1980 's that evaluated the diets of mothers and children in Kenya, Mexico, and Egypt. In one or more of the study sites, there were positive associations between pre-partum intake of ASF and neurobehavioral development of the infant. Positive correlations were also found with infant growth rates and maternal consumption of ASF while breastfeeding [57]. Another 2-year intervention study of Kenyan schoolchildren showed that the addition of a snack with $200-250 \mathrm{mls}$ of milk per school day and a total of $240 \mathrm{kcal}$ improved height in young children ( $<6$ year olds) and already stunted children. The same study showed that the addition of 60-85 grams of red meat and a total addition of $240 \mathrm{kcal}$ improved the children's cognitive and school performance, and increased the time spent doing physical activity at play [31, 32]. While the answer to "how much/how often" to prevent stunting, is quantitatively unknown, it is clear that even small amounts of ASF consumed 5-6 days per week and by pregnant and lactating mothers can improve the physical and cognitive development of her child. Research addressing this question is absolutely necessary for the implementation of cost-effective interventions that aim to improve child health outcomes through increased accessibility to ASF.

\section{How would a decrease in the cost of ASF impact consumption in the urban slums? How would an increase in income (real income or aid income) in the urban slums affect ASF consumption?}

Data analyzed from a 2003 Tegemeo Institute household survey in Nairobi indicates that ASF tend to have high price and income elasticities of demand for the urban poor [50]. Despite disaggregation by income, many household surveys fail to capture the situation facing those living in the informal settlements. First, slum populations are often under-sampled due to lack of legal recognition of informal settlements, deterrence by real or perceived high crime rates, and logistical problems resulting from fluid populations and the absence of household addresses or maps [2, 58]. Secondly, different settlements around Nairobi are ethnically and culturally heterogeneous, factors that impact the consumption of different ASF. Extrapolating data directly from one settlement to another may be poorly representative. Thus, understanding the price and income elasticities of demand for ASF in individual settlements remains an important knowledge gap. This economic data is necessary to inform and measure the impact of targeted policies and interventions that would increase consumption of ASF, such as food subsidy 
and cash transfer programs. Such interventions must also be rigorously assessed with anthropometric surveys to determine the health impacts for families living in these environments.

\section{What pro-poor point-of-sale marketing and packaging would encourage greater consumption of ASF by the urban poor?}

To increase consumption of ASF in the slums, it must not only be available, it also must be sold in quantities and avenues that make it accessible to those at greatest risk of undernourishment. Research regarding marketing and packaging strategies that aim to increase the purchase of ASF by the urban poor is lacking. This data would be beneficial two-fold; it would likely provide economic incentives for retail shop owners to reconsider how ASF is being sold, and in turn, improve accessibility and consumption of ASF for those living in the informal settlements. Educational interventions using this data should focus on retail shop owners in both informal and formal sectors, with the ultimate goal of improving the nutritional health and economic well-being of the population.

What is the contribution of enteric disease to stunting rates in the urban slums? Can ASF alleviate stunting rates despite repeated or constant exposure to pathogens?

No discussion of childhood stunting in relation to nutrition would be complete without acknowledging the impact of the environment on growth outcomes. Infectious diarrheal disease and malnutrition have a synergistic relationship, whereby malnutrition predisposes a child to diarrhea, and recurrent diarrhea is a risk factor for malnutrition [59-61]. Compounded with dietary inadequacies, children in the slum environment are exposed to a number of pathogens due to the lack of waste management systems, limited access to clean water, and overcrowding. Diarrhea prevalence for children under three years of age in the slums is $20 \%$, with $7 \%$ having hemorrhagic diarrhea. The prevalence of diarrhea with blood is more than double the national average, and more than 10 times that of Nairobi as a whole [62].

What is the contribution of diarrhea in the informal settlements to anthropometric measures of malnutrition? Numerous studies have demonstrated that children with repeat episodes of diarrhea are at greater risk for stunting [60,63-65]. Growth failure is a consequence of energy and micronutrient deficiencies from impaired enteric absorption, inappetence, and increased catabolism of nutrients. In turn, undernourished children are at greater risk for diarrhea from a weakened immune system and a dysfunctional gut mucosal barrier that protects against pathogens. Clearly, the reciprocal relationship between stunting and episodic diarrhea is difficult to escape in the urban slum environment. The role of subclinical enteric disease, or environmental enteropathy, on stunting rates is also relevant. Environmental enteropathy affects those living in areas with essentially constant exposure to enteric pathogens, and is characterized by chronic intestinal inflammation and blunting of intestinal villi. These pathologic changes result in aberrations in gut immunity and absorptive capacity, changes that may result in growth failure $[66,67]$. A 2008 modeling study found that in the 36 countries where the majority of stunted children live, $99 \%$ coverage of existing nutritional interventions would result in only $35.5 \%$ reduction of stunting prevalence [68]. This model suggests that a significant proportion of stunting results from non-nutritional factors, such as clinical or subclinical enteritis, including environmental enteropathy. Disaggregating the impact of enteric disease on stunting, however, as opposed to the impact of undernutrition or malnutrition, is difficult. In environments of extreme poverty, such as the informal settlements, food insecurity is prevalent and the risk for pathogen exposure is high. Nevertheless, the use of ASF interventions to curb stunting prevalence has shown promise [32, 69, 70]. The number of reports describing such interventions is relatively small, thus ASF interventions were not specifically analyzed as part of 2008 study described above [68]. Moreover, improvements in gut function and intestinal histological changes have been demonstrated in cases of environmental enteropathy after supplementation with vitamin A, zinc, and glutamine, all of which are supplied by $\operatorname{ASF}[20,66,71]$. While more evaluation must be done, this leaves open the intriguing possibility that the highly bioavailable nutrients and calories supplied by ASF may improve enteric function despite intense exposure to pathogens.

\section{CONCLUSION}

Food insecurity is a chronic problem among the poor living in informal urban settlements and is manifested in persistently high rates of child stunting. The intergenerational and cyclic nature of factors associated with poor child nutritional health outcomes underscores the need for sustainable interventions. Addressing the knowledge gaps highlighted in this review will provide new opportunities to develop, 
implement, and assess interventions, including market and policy changes, to enhance nutrition for the food insecure living within urban informal settlements. Despite these knowledge gaps, program managers and policy makers can increase consumption of ASF by implementing evidence-based interventions using current data:

- The urban poor consume inadequate amounts of animal protein due to an inability to pay for these commodities. Beef, chicken, eggs, and unpasteurized milk are the most commonly consumed ASF by poor populations in Nairobi. Thus, interventions and policies should be centered on improving accessibility to these foods, as they are available in markets where the urban poor frequent.

- Programs that aim to incentivize pro-poor marketing and packaging strategies for ASF will increase the purchase of these foods by the urban poor. Such strategies include selling smaller cuts of meat that retain the low cost of undivided, larger quantities. This approach will improve the market accessibility of ASF for those with low purchasing power.

- Econometric data suggests that decreases in the price of ASF disproportionately increases demand. Thus, policies that reduce market barriers for the poor, such as subsidy programs, encourage greater consumption of ASF by effectively reducing their cost. Subsidies also protect consumers from food price shocks that induce coping strategies detrimental to nutritional health. Likewise, policies that decrease the cost of ASF at any point in the food value chain, such as lowering import tariffs or consumer taxes, may positively influence the purchase of these foods by the urban poor.

- Income elasticity studies reveal that increases in household expenditure result in disproportionate increases in demand for ASF. Cash transfer and voucher aid programs can use this data to effectively increase income, resulting in greater consumption of ASF and improved nutritional health outcomes.

- Regulatory policies concerning ASF must be considerate of potential undesirable nutritional health consequences for vulnerable urban populations. The ban on raw milk sales, for example, in the informal market may exclude the urban poor from consumption of liquid milk due to the increased cost of pasteurized milk. Similarly, policies that ban the use of antimicrobials in food animals may increase the costs of production, and be passed on to the consumer. While policies like these are well intentioned from a food safety standpoint, they may bring the unintended effect of worsening the food insecurity crisis in the urban slums by making ASF less accessible.

\section{ACKNOWLEDGEMENTS}

We would like to acknowledge Dr. Jon Yoder and Dr. Tom Marsh for their critical review and helpful comments in assembling this manuscript, and for providing their expertise on the economic data presented herein.

\section{REFERENCES}

[1] United Nations. World urbanization prospects: The 2011 revision. New York: UN-DESA; 2012.

[2] United Nations. The challenge of the slums: Global report on human settlements 2003. Nairobi: UN-HABITAT; 2003.

[3] Mohiddin L, Phelps L, Walter T. Urban malnutrition: A review of food security and nutrition among the urban poor United Kingdom: Nutrition Works; 2012 [cited 12 July 2014]. Available from: http://www.alnap.org/resource/8602.

[4] Kenya National Bureau of Statistics. County population 2010 [cited 11 July 2014]. Available from: https://www.knbs.or.ke/ index.php.

[5] United Nations. Nairobi urban sector profile. Nairobi: UNHABITAT; 2006.

[6] Mutisya E, Yarime M. Understanding the grassroots dynamics of slums in Nairobi: The dilemma of Kibera informal settlements. Int Trans J Eng Manag Sci Tech 2011; 2: 197213.

[7] The World Bank. Urban population growth (Kenya) 2012 [cited 11 July 2014]. Available from: http://search.worldbank. org.

[8] Zulu EM, Beguy D, Ezeh AC, et al. Overview of migration, poverty and health dynamics in Nairobi City's slum settlements. J Urban Health 2011; 88 (Suppl 2): S185-99. http://dx.doi.org/10.1007/s11524-011-9595-0

[9] Olack B, Burke $H$, Cosmas $L$, et al. Nutritional status of under-five children living in an informal urban settlement in Nairobi, Kenya. J Health Popul Nutr 2011; 29: 357-63. http://dx.doi.org/10.3329/jhpn.v29i4.8451

[10] Kenya National Bureau of Statistics (KNBS), ICF Macro. Kenya demographic and health survey 2008-09. Calverton, MD: KNBS and ICF Macro; 2010. Available from: http://dhsprogram.com/pubs/pdf/fr229/fr229.pdf.

[11] Lewit EM, Kerrebrock N. Population-based growth stunting. Future Child 1997; 7: 149-56. http://dx.doi.org/10.2307/1602393

[12] Black RE, Allen LH, Bhutta ZA, et al. Maternal and child undernutrition: global and regional exposures and health consequences. Lancet 2008; 371: 243-60. http://dx.doi.org/10.1016/S0140-6736(07)61690-0 
[13] United Nations. Improving child nutrition: The achievable imperative for global progress. New York: UNICEF; 2013.

[14] Bryce J, Boschi-Pinto C, Shibuya K, Black RE. WHO estimates of the causes of death in children. Lancet 2005; 365: 1147-52.

http://dx.doi.org/10.1016/S0140-6736(05)71877-8

[15] Black RE, Victora CG, Walker SP, et al. Maternal and child undernutrition and overweight in low-income and middleincome countries. Lancet 2013; 382: 427-51. http://dx.doi.org/10.1016/S0140-6736(13)60937-X

[16] Moore SE, Jalil F, Ashraf R, Szu SC, Prentice AM, Hanson LA. Birth weight predicts response to vaccination in adults born in an urban slum in Lahore, Pakistan. Am J Clin Nutr 2004; 80: 453-9.

[17] Victora CG, Adair L, Fall C, et al. Maternal and child undernutrition 2 - Maternal and child undernutrition: consequences for adult health and human capital. Lancet 2008; 371: 340-57. http://dx.doi.org/10.1016/S0140-6736(07)61692-4

[18] Gewa CA. Childhood overweight and obesity among Kenyan pre-school children: association with maternal and early child nutritional factors. Public Health Nutr 2010; 13: 496-503. http://dx.doi.org/10.1017/S136898000999187X

[19] Schonfeldt HC, Gibson Hall N. Dietary protein quality and malnutrition in Africa. Br J Nutr 2012; 108 (Suppl 2): S69-76.

[20] Neumann C, Harris DM, Rogers LM. Contribution of animal source foods in improving diet quality and function in children in the developing world. Nutr Res 2002; 22: 193-220. http://dx.doi.org/10.1016/S0271-5317(01)00374-8

[21] Muller O, Krawinkel M. Malnutrition and health in developing countries. Can Med Assoc J 2005; 173: 279-86. http://dx.doi.org/10.1503/cmaj.050342

[22] Grantham-McGregor S, Cheung YB, Cueto S, Glewwe P, Richter L, Strupp B. Developmental potential in the first 5 years for children in developing countries. Lancet 2007; 369: 60-70. http://dx.doi.org/10.1016/S0140-6736(07)60032-4

[23] Alderman $\mathrm{H}$. Long term consequences of early childhood malnutrition. Oxford Econ Pap 2006; 58: 450-74. http://dx.doi.org/10.1093/oep/gpl008

[24] Heltberg R. Malnutrition, poverty, and economic growth. Health Econ 2009; 18 (Suppl 1): S77-88.

[25] Strauss J, Thomas D. Health, nutrition, and economic development. J Econ Lit 1998; 36: 766-817.

[26] Fogel RW. Health, nutrition, and economic growth. Econ Dev Cult Change 2004; 52: 643-58. http://dx.doi.org/10.1086/383450

[27] World Health Organization. Food security [cited 26 June 2014]. Available from: http://www.who.int/trade/glossary/ story028/en/.

[28] Kamau M, Githuku J, Olwande J. Food security in urban households: An analysis of the prevalence and depth of hunger in Nairobi and its relationship to food expenditure (WPS 41/2011b) Nairobi, Kenya: Tegemeo Institute of Agricultural Policy and Development; 2011. Available from: http://tegemeo.org/.

[29] Kamau M, Olwande J, Githuku J. Consumption and expenditures on key food commodities in urban households: The case of Nairobi (WPS 41/2011a) Nairobi, Kenya: Tegemeo Institute of Agricultural Policy and Development; 2011. Available from: http://tegemeo.org/.

[30] Allen LH. Nutritional influences on linear growth: a general review. Eur J Clin Nutr 1994; 48 (Suppl 1): S75-89.

[31] Neumann CG, Bwibo NO, Murphy SP, et al. Animal source foods improve dietary quality, micronutrient status, growth and cognitive function in Kenyan school children: background, study design and baseline findings. J Nutr 2003; 133(Suppl 2): 3941S-9S.
[32] Neumann CG, Murphy SP, Gewa C, Grillenberger M, Bwibo NO. Meat supplementation improves growth, cognitive, and behavioral outcomes in Kenyan children. J Nutr 2007; 137: 1119-23.

[33] Whaley SE, Sigman M, Neumann C, et al. The impact of dietary intervention on the cognitive development of Kenyan school children. J Nutr 2003; 133: 3965s-71s.

[34] Grillenberger M, Neumann CG, Murphy SP, et al. Food supplements have a positive impact on weight gain and the addition of animal source foods increases lean body mass of Kenyan schoolchildren. J Nutr 2003; 133: 3957s-64s. http://dx.doi.org/10.1079/BJN20051641

[35] Grillenberger M, Neumann CG, Murphy SP, et al. Intake of micronutrients high in animal-source foods is associated with better growth in rural Kenyan school children. Br J Nutr 2006; 95: 379-90.

[36] Murphy SP, Allen LH. Nutritional importance of animal source foods. J Nutr 2003; 133: 3932s-5s.

[37] Hurrell RF. Influence of vegetable protein sources on trace element and mineral bioavailability. J Nutr 2003; 133: 2973s7s.

[38] Gibson RS. Content and bioavailability of trace-elements in vegetarian diets. Am J Clin Nutr 1994; 59: S1223-S32.

[39] Ettarh R, Van de Vijver S, Oti S, Kyobutungi C. Overweight, obesity, and perception of body image among slum residents in Nairobi, Kenya, 2008-2009. Prev Chronic Dis 2013; 10: E212.

[40] Popkin BM. Global nutrition dynamics: the world is shifting rapidly toward a diet linked with noncommunicable diseases. Am J Clin Nutr 2006; 84: 289-98.

[41] Ziraba AK, Fotso JC, Ochako R. Overweight and obesity in urban Africa: A problem of the rich or the poor? BMC Public Health 2009; 9: 465.

http://dx.doi.org/10.1186/1471-2458-9-465

[42] van 't Riet $H$, den Hartog AP, Mwangi AM, Mwadime RK, Foeken DW, van Staveren WA. The role of street foods in the dietary pattern of two low-income groups in Nairobi. Eur $\mathrm{J}$ Clin Nutr 2001; 55: 562-70.

http://dx.doi.org/10.1038/sj.ejcn. 1601183

[43] Steyn NP, Nel JH, Parker WA, Ayah R, Mbithe D. Dietary, social, and environmental determinants of obesity in Kenyan women. Scand J Public Health 2011; 39: 88-97. http://dx.doi.org/10.1177/1403494810384426

[44] Gamba P. Urban domestic consumption patterns for meat: Trends and policy implications (WP 17/2005) Nairobi, Kenya: Tegemeo Institute of Agricultural Policy and Development; 2005. Available from: http://tegemeo.org/.

[45] Argwings-Kodhek G, M'mboyi G, Muyanga M, Gamba P. Consumption patterns of dairy products in Kenya's urban centres: Report from an urban household survey (WP 18/2005) Nairobi, Kenya: Tegemeo Institute of Agricultural Policy and Development; 2005. Available from http://tegemeo.org/.

[46] Food and Agriculture Organization of the United Nations. Meat consumption [cited 31 July 2013]. Available from: http://www.fao.org/ag/againfo/themes/en/meat/background.ht $\mathrm{ml}$.

[47] Michelson H, Lentz EC, Mulwa R, et al. Cash, food, or vouchers in urban and rural Kenya? An application of the market information and food insecurity response analysis framework: SSRN; 2011. http://dx.doi.org/10.2139/ssrn.1844594

[48] Kenya Food Security Steering Group (KFSSG). The 2008/'09 short-rains season assessment report: KFSSG; 2009. Available from: http://reliefweb.int/sites/reliefweb.int/files/ resources/828585AE5D12C0CF492575800027F6AAFull_Report.pdf. 
[49] Andreyeva T, Long MW, Brownell KD. The impact of food prices on consumption: a systematic review of research on the price elasticity of demand for food. Am J Public Health 2010; 100: 216-22.

http://dx.doi.org/10.2105/AJPH.2008.151415

[50] Musyoka MP, Lagat JK, Ouma DE, Wambua T, Gamba P. Structure and properties of urban household food demand in Nairobi, Kenya: implications for urban food security. Food Sec 2010; 2: 179-93. http://dx.doi.org/10.1007/s12571-010-0063-6

[51] Pinstrup-Anderson P. Food prices and the poor in developing countries. Euro R Agr Eco 1985; : 69-85.

[52] Food and Agriculture Organization of the United Nations. The state of food insecurity in the world, 2008. Rome: FAO, 2008. http://dx.doi.org/10.1007/s11524-011-9594-1

[53] Bett HK, Musyoka MP, Peters KJ, Bokelmann W. Demand for meat in the rural and urban areas of Kenya: A focus on the indigenous chicken. Economics Res Int [Internet]. 2012; Article ID 401472:[10 p.]. http://dx.doi.org/10.1155/2012/401472

[54] Juma GP, Ngigi M, Baltenweck I, Drucker AG. Consumer demand for sheep and goat meat in Kenya. Small Ruminant Res 2010; 90: 135-8. http://dx.doi.org/10.1016/j.smallrumres.2009.12.002

[55] Emina J, Beguy D, Zulu EM, et al. Monitoring of health and demographic outcomes in poor urban settlements: evidence from the Nairobi Urban Health and Demographic Surveillance System. J Urban Health 2011; 88 (Suppl 2): S200-18.

[56] Fiszbein A, Schady N. Conditional cash transfers; Reducing present and future poverty. Washington, D.C.: The World Bank, 2009. http://dx.doi.org/10.1596/978-0-8213-7352-1

[57] Allen LH. The nutrition Crsp: What is marginal malnutrition, and does it affect human function? Nutr Rev 1993; 51: 25567.

http://dx.doi.org/10.1111/j.1753-4887.1993.tb03117.x

[58] Satterthwaite $D$. The under-estimation of urban poverty in low and middle-income nations (WP 14) London, UK: UK Department for International Development; 2004. Available from: http://pubs.iied.org/9322IIED.html.

[59] Brown KH. Diarrhea and malnutrition. J Nutr 2003; 133: 328s-32s.

[60] Guerrant RL, Oria RB, Moore SR, Oria MO, Lima AA. Malnutrition as an enteric infectious disease with long-term effects on child development. Nutr Rev 2008; 66: 487-505. http://dx.doi.org/10.1111/j.1753-4887.2008.00082.x
[61] Dewey KG, Mayers DR. Early child growth: How do nutrition and infection interact? Matern Child Nutr 2011; 7 (Suppl 3): 129-42.

http://dx.doi.org/10.1111/1.1740-8709.2011.00357.x

[62] African Population and Health Research Center (APHRC). Population and health dynamics in Nairobi's informal settlements: Report of the Nairobi Cross-sectional Slums Survey (NCSS) 2012 Nairobi: APHRC; 2014. Available from: http://aphrc.org/wp-content/uploads/2014/08/NCSS2-FINALReport.pdf.

[63] Rice AL, Sacco L, Hyder A, Black RE. Malnutrition as an underlying cause of childhood deaths associated with infectious diseases in developing countries. B World Health Organ 2000; 78: 1207-21.

[64] Moore SR, Lima AA, Conaway MR, Schorling JB, Soares AM, Guerrant RL. Early childhood diarrhoea and helminthiases associate with long-term linear growth faltering. Int J Epidemiol 2001; 30: 1457-64. http://dx.doi.org/10.1093/ije/30.6.1457

[65] Richard SA, Black RE, Gilman $\mathrm{RH}$, et al. Diarrhea in early childhood: short-term association with weight and long-term association with length. Am J Epidemiol 2013; 178: 1129-38. http://dx.doi.org/10.1093/aje/kwt094

[66] Korpe PS, Petri WA, Jr. Environmental enteropathy: critical implications of a poorly understood condition. Trends $\mathrm{Mol}$ Med 2012; 18: 328-36 http://dx.doi.org/10.1016/j.molmed.2012.04.007

[67] Keusch GT, Rosenberg IH, Denno DM, et al. Implications of acquired environmental enteric dysfunction for growth and stunting in infants and children living in low- and middleincome countries. Food Nutr Bull 2013; 34: 357-64.

[68] Bhutta ZA, Ahmed T, Black RE, et al. What works? Interventions for maternal and child undernutrition and survival. Lancet 2008; 371: 417-40. http://dx.doi.org/10.1016/S0140-6736(07)61693-6

[69] Darapheak C, Takano T, Kizuki M, Nakamura K, Seino K Consumption of animal source foods and dietary diversity reduce stunting in children in Cambodia. Int Arch Med 2013 6: 29. http://dx.doi.org/10.1186/1755-7682-6-29

[70] Krebs NF, Mazariegos M, Tshefu A, et al. Meat consumption is associated with less stunting among toddlers in four diverse low-income settings. Food Nutr Bull 2011; 32: 18591.

[71] McKay S, Gaudier E, Campbell DI, Prentice AM, Albers R. Environmental enteropathy: new targets for nutritional interventions. Int Health 2010; 2: 172-80. http://dx.doi.org/10.1016/j.inhe.2010.07.006

http://dx.doi.org/10.6000/1929-4247.2015.04.02.5

(C) 2015 James and Palmer; Licensee Lifescience Global.

This is an open access article licensed under the terms of the Creative Commons Attribution Non-Commercial License (http://creativecommons.org/licenses/by-nc/3.0/) which permits unrestricted, non-commercial use, distribution and reproduction in any medium, provided the work is properly cited. 